\title{
PEMBELAJARAN EXAMPLE NON EXAMPLE UNTUK MENINGKATKAN HASIL BELAJAR BIOLOGI
}

\author{
Anisa \\ Prodi Pendidikan Biologi, FKIP, Universitas Muhammadiyah Makassar, Indonesia \\ anisa@unismuh.ac.id
}

\begin{abstract}
Abstrak
Penelitian Tindakan Kelas (Classroom Action Research) ini bertujuan untuk meningkatkan aktivitas dan hasil belajar siswa melalui model Pembelajaran example non example. Subjek penelitian ini adalah 32 orang siswa kelas $X_{5}$ SMA Negeri 15 Makassar pada Semester Genap 2010/2011. Pelaksanaan penelitian ini terdiri atas dua siklus, data aktivitas dan hasil belajar siswa dianalisis dengan menggunakan analisis kuantitatif. Hasil penelitian menunjukkan bahwa penerapan model pembelajaran kooperatif tipe example non example meningkatkan hasil belajar siswa kelas $\mathrm{X}_{5}$ SMA Negeri 15 Makassar. Peningkatan tersebut ditunjukkan oleh hasil penelitian dari siklus I ke siklus II, yaitu, ratarata nilai hasil belajar siswa meningkat dari 57, 96 menjadi 78,01. disertai juga dengan peningkatan aktivitas siswa mengamati gambar, menganalisa gambar, bekerjasama dengan kelompoknya, mengajukan pertanyaan yang terkait dengan materi pelajaran, mengemukakan tanggapan dan meminta bimbingan guru. Disimpulkan bahwa terjadi peningkatan hasil belajar siswa kelas $\mathrm{X}_{5}$ SMA Negeri 15 Makassar Gowa.
\end{abstract}

Kata Kunci: Example non example, Hasil Belajar.

Published by:

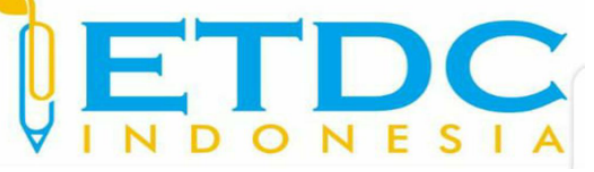

Copyright (C) 2021 The Author (s)

This article is licensed under CC BY 4.0 License

(cc) $\mathrm{BY}$ 


\section{PEMBELAJARAN EXAMPLE NON EXAMPLE UNTUK MENINGKATKAN HASIL BELAJAR BIOLOGI}

\section{Pendahuluan}

Era globalisasi telah mendera berbagai bidang kehidupan. Persaingan pun semakin tinggi, serta tantangan dan permasalahan kehidupan yang semakin kompleks telah menanti untuk dijawab dan diselesaikan. Untuk dapat menghadapi persaingan, tantangan dan berbagai permasalahan di berbagai bidang kehidupan maka dibutuhkan sumber daya manusia yang berkualitas dan berkompetensi.

Berbagai upaya telah dilakukan oleh pemerintah untuk menghasilkan sumber daya manusia yang berkualitas dan berkompetensi. Salah satu upaya yang dilakukan oleh pemerintah adalah memperbaiki mutu pendidikan di Indonesia. Upaya peningkatan mutu pendidikan diharapkan mampu menghasilkan lulusan yang memiliki daya saing tinggi dan mampu menghadapi tantangan.

Upaya peningkatan mutu pendidikan tidak dapat lepas dari usaha-usaha peningkatan hasil belajar siswa di sekolah-sekolah. Berbagai pihak di sekolah memiliki peranannya masingmasing di dalam peningkatan hasil belajar siswa tersebut. Guru merupakan salah satu pihak yang memegang peranan penting dalam upaya peningkatan hasil belajar siswa. Hal ini disebabkan karena gurulah yang berinteraksi langsung dengan siswa-siswa dalam proses pembelajaran.

Guru diharapkan mampu untuk mengelola proses pembelajaran di kelas agar dapat berjalan secara maksimal. Dapat mengaktifkan seluruh siswa selama proses pembelajaran. Di mana pembelajaran bukan lagi terpusat pada guru (teacher centered) tetapi telah terpusat pada siswa (student centered). Di dalam proses pembelajaran siswa diharapkan lebih aktif dalam menggali informasi-informasi, dimana guru berperan sebagai fasilitator dan siswalah yang kemudian aktif dalam menggali informasi mengenai pelajaran yang dibawakan oleh guru.

Kenyataan yang terjadi di lapangan, siswa masih belum aktif dalam proses pembelajaran. Selama proses pembelajaran masih terkesan bahwa pembelajaran masih terpusat pada guru (teacher centered), siswa hanya menerima apa yang diberikan oleh guru selama proses pembelajaran berlangsung dan pada akhirnya siswa hanya menghapal materi yang dibawakan oleh guru.

Rendahnya hasil belajar siswa disebabkan oleh kurangnya motivasi belajar siswa, dalam pembelajaran. Selain itu dalam proses pembelajaran guru masih sering menggunakan metode ceramah dan siswa menjadi pendengar. Keaktifan siswa di dalam proses pembelajaran masih 
kurang. Keaktifan siswa hanya sebatas pada mengajukan pertanyaan dan menjawab pertanyaan yang diberikan oleh guru. Siswa kurang aktif untuk mencari dan menggali informasi mengenai topik yang dibawakan oleh guru secara mandiri. Mereka hanya menerima segala informasi yang diberikan oleh guru selama proses pembelajaran berlangsung. Informasi mengenai materi pelajaran kurang membekas di benak mereka, saat akan tiba masa ujian pun mereka lebih banyak menghapal materi yang diberikan sehingga pada saat ujian hasil yang didapatkan kurang maksimal. Masih banyak siswa yang belum mencapai ketuntasan dan mengikuti remedial. Selain itu, selama proses pembelajaran siswa cenderung pasif dan masih banyak melakukan kegiatan yang tidak ada hubungannya dengan pembelajaran.

Penggunaan metode ceramah tanpa ada variasi pada pembelajaran IPA-Biologi dapat menimbulkan rasa bosan bagi peserta didik, karena mereka tidak diaktifkan secara penuh dalam kegiatan pembelajaran. Guru terkadang asyik sendiri berceramah di depan peserta didiknya, sehingga mengakibatkan peserta didik menjadi pasif. Penggunaan metode ceramah, dapat merugikan peserta didik yang tidak terampil membuat catatan dan menyimak. Selain itu, dapat mengakibatkan peserta didik bersikap untuk selalu menerima, kurang kreatif dan kurang kritis

Salah satu upaya yang dapat dilakukan untuk meningkatkan keaktifan siswa dalam proses pembelajaran adalah dengan menerapkan model pembelajaran kooperatif. Melalui penerapan pembelaran kooperatif diharapkan keaktifan siswa akan meningkat dan diiringi dengan peningkatan hasil belajar pula. Hal ini sesuai dengan penelitian yang dilakukan oleh (Suryani et al., 2018) bahwa meningkatnya hasil belajar siswa dikarenakan penggunaan model pembelajaran example non example dapat membuat siswa untuk belajar secara aktif.

\section{Metode Penelitian}

Penelitian ini berjenis classroom action research, menurut (Sugiyono, 2017) penelitian ini memiliki tahapan-tahapan pelaksanaan meliputi: perencanaan, pelaksanaan, tindakan, evaluasi dan refleksi secara berulang. Subyek penelitian ini adalah siswa kelas $\mathrm{X}_{5} \mathrm{SMANegeri}$ 15 Makassar tahun ajaran 2010/2011 yang berjumlah 32 siswa. Adapun faktor yang diselidiki dalam penelitian ini adalah hasil belajar biologi siswa setelah diajar dengan menggunakan model pembelajaran example non example.

Instrumen digunakan untuk memudahkan pengumpulan data (Arikunto, 2013). Adapun instrumen yang digunakan dalam penelitian ini ini adalah tes hasil belajar yang berupa pilihan ganda berjumlah 30 nomor. Teknik pengumpulan data hasil belajar siswa diperoleh melalui tes hasil belajar di setiap akhir siklus. Teknik analisis data yang digunakan untuk mengolah data dengan statistik deskriptif. 


\section{Hasil dan Pembahasan}

Data hasil belajar biologi siswa kelas $\mathrm{X}_{5}$ SMA Negeri 15 Makassar pada siklus I dan siklus II yang diperoleh dari tes hasil belajar pada setiap akhir siklus. Distribusi nilai hasil belajar siswa kelas $\mathrm{X}_{5}$ SMA Negeri 15 Makassar setelah dikelompokkan ke dalam lima kategori dapat dilihat pada tabel berikut.

Tabel 1. Distribusi Frekuensi dan Kategorisasi Nilai Hasil Belajar Biologi Siswa melalui Penerapan Model Pembelajaran Kooperatif tipe Examples Non Examples

\begin{tabular}{clcccc}
\hline \multirow{2}{*}{ Skor } & \multirow{2}{*}{ Kriteria } & \multicolumn{2}{c}{ Frekuensi } & \multicolumn{2}{c}{ Persentase (\%) } \\
\cline { 3 - 6 } & & Siklus I & Siklus II & Siklus I & Siklus II \\
\hline $80-100$ & Baik Sekali & 3 & 12 & 9.375 & 37.5 \\
$66-79$ & Baik & 8 & 14 & 25 & 43.75 \\
$56-65$ & Cukup & 11 & 4 & 34.375 & 12.5 \\
$40-55$ & Kurang & 7 & 2 & 21.875 & 6.25 \\
$0-39$ & Kurang Sekali & 3 & 0 & 9.375 & 0 \\
& Jumlah & 32 & 32 & 100 & 100 \\
\hline
\end{tabular}

Tabel. 1 di atas menunjukkan bahwa pada siklus I sebesar $34,375 \%$ siswa berada pada kategori cukup dan masih terdapat sejumlah siswa yang berada pada kriteria kurang sekali yaitu sebesar 9,375\%. Pada siklus II mengalami peningkatan, tidak ditemukan siswa dengan nilai kurang sekali. Persentase terbesar ditunjukkan oleh siswa yang masuk ke dalam kriteria baik yaitu sebesar 43, $75 \%$. nilai rata-rata hasil belajar mengalami peningkatan yaitu dari 57,96 menjadi 78,01 .

Hasil penelitian aktifitas belajar siswa kelas $\mathrm{X}_{5}$ SMA Negeri 15 Makassar menunjukkan bahwa penerapan model pembelajaran kooperatif tipe example non example dapat meningkatkan aktivitas belajar siswa. Berdasarkan hasil pengamatan yang dilakukan selama proses pembelajaran, terlihat adanya peningkatan aktivitas belajar siswa yang ditandai dengan meningkatnya keaktifan siswa di dalam diskusi, baik diskusi kelompok maupun diskusi kelas.

Hal senada juga dengan hasil penelitian yang dilakukan oleh situasi belajar saat menggunakan model example non example menjadi lebih hidup, kondisi kelas ramai dengan suara mahasiswa saat berdiskusi. setiap anggota kelompok berperan aktif dalam kegiatan kelompok, mereka melakukan aktifitas seperti mengamati gambar, berdiskusi, membaca literature hingga kegiatan menyimpulkan dan mempersiapkan bahan presentasi mereka. Model example non example dapat membantu mahasiswa untuk berpikir kritis untuk menganalisis sesuatu sehingga mahasiswa dilatih untuk memiliki kompetensi pada ranah kognitif level C4. (Soenarno \& Sari, 2020) 
Pembelajaran dengan menggunakan Examples Non Exameples memberikan kondisi belajar dimana siswa harus mencari informasi mengenai materi pelajaran secara mandiri. Bersama dengan kelompoknya siswa berdiskusi untuk menemukan menemukan informasi tersebut, kemudian melakukan diskusi dengan kelompok lain melalui presentasi hasil diskusi kelompoknya di depan kelas. Setiap kelompok diberikan kesempatan untuk mempresentasikan hasil diskusi kelompoknya. Hal tersebut dapat menumbuhkan keaktifan siswa di dalam pembelajaran

Berdasarkan hasil penelitian yang dilakukan oleh (Susanti, 2014) melalui pembelajaran example non example siswa mulai terbiasa mengerjakan tugas bersama dengan kelompoknya, dapat menghargai ide temannya, serta beberapa siswa sudah mamu untuk menyampaikan ide pada kelompoknya, berani untuk presentasi serta menerima tanggapan dari kelompok lain dan dapat menarik kesimpulan hasil pembelajaran.

Pembelajaran dengan menggunakan examples non examples memberikan kondisi belajar dimana siswa harus mencari informasi mengenai materi pelajaran secara mandiri. Bersama dengan kelompoknya siswa berdiskusi untuk menemukan menemukan informasi tersebut, kemudian melakukan diskusi dengan kelompok lain melalui presentasi hasil diskusi kelompoknya di depan kelas. Setiap kelompok diberikan kesempatan untuk mempresentasikan hasil diskusi kelompoknya. Hal tersebut dapat menumbuhkan keaktifan siswa di dalam pembelajaran

Melalui pembelajaran example non example mahasiswa dapat lebih mendalami konsep yang sedang mereka pelajar. Mahasiswa pun menjadi lebih aktif dalam proses pembelajaran, hal ini tentu berpengaruh pada nilai ujian mereka. Nilai tes objektif mahasiswa setelah dibelajarkan dengan mode example non example meningkat (Soenarno \& Sari, 2020)

Keaktifan siswa dalam pembelajaran sangatlah penting. Siswa akan aktif dalam menggali informasi-informasi mengenai materi pelajaran yang diajarkan. Jika siswa sendiri yang mencari informasi tersebut maka, akan lebih lama tersimpan di dalam ingatan. Melalui Examples Non Examples memberikan kesempatan kepada siswa untuk menemukan sendiri informasi mengenai materi pelajaran melalui diskusi kelompok serta memahami lebih dalam materi tersebut melalui contoh-contoh yang diberikan dalam bentuk lembar kegiatan.

Keaktifan siswa di kelas tentunya merupakan harapan di setiap proses pembelajaran. Namun, terkadang jika siswa asyik berdiskusi akan menimbulkan suasana yang gaduh. Seperti penelitian yang dilakukan oleh (Tulhikmah, 2019) untuk meningkatkan kualitas proses pembelajaran example non example dapat dilakukan beberapa cara antara lain, bersikap tegas serta memberikan dan arahan kepada semua kelompok sehingga siswa tidak ribut dan 
mengantuk.

Penelitian yang dilakukan oleh (Djafar, 2014) menunjukkan bahwa tidak hanya hasil belajar yang meningkat setelah dilakukan pembelajaran dengan model example non example tetapi juga kemampuan berpikir kritis. Hal ini karena selama proses pembelajaran, lebih menekankan siswa untuk mengasah kemampuan analisis terkait mencari informasi yang benar dari setiap gambar yang ditayangkan, mencari penjelasan sebanyak mungkin dan bersikap sistematis dalam mengerjakan tugas. Sependapat dengan hal tersebut (Leonard \& Wulandari, 2015)juga menegaskan melalui hasil penelitiannya bahwa melalui gambar dan contoh-contoh yang disajikan pada pembelajaran example non example siswa didorong untuk berpikir untuk memecahkan masalah.

Selain itu model pembelajaran example non example juga dapat dikombinasikan dengan penggunakan berbagai metode dan media pembelajaran lainnya sehingga pembelajaran akan lebih bervariasi dan menarik. Seperti penelitian yang dilakukan oleh (Sabroni et al., 2018) dengan menggunakan model example non example berbantuan poster comment dapat meningkatkan pemahaman konsep siswa.

Berdasarkan pembahasan di atas untuk menciptakan suasana belajar yang menarik dan interaktif bagi siswa, salah satunya dengan menggunakan model pembelajaran example non example yang dapat pula diintegrasikan dengan berbagai metode dan media. Namun, perlu juga diperhatikan berbagai faktor internal dan eksternal siswa selama pembelajaran. Salah satu faktor internal dari diri siswa adalah tingkat prokrastinasi akademik, seperti penelitian yang dilakukan oleh (Anisa \& Ernawati, 2018) bahwa prokrastinasi akademik berpengaruh negatif terhadap hasil belajar. prokrastinasi akademik merupakan perilaku menunda untuk menyelesaikan tugas akademik oleh siswa. Selain itu, masih banyak faktor lain yang berasal dari dalam diri siswa adalah motivasi dan minat belajar siswa. Oleh karena itu sebagai seorang pendidik dapat memperhatikan faktor-faktor yang mempengaruhi hasil belajar siswa agar siswa dapat meraih prestasi yang gemilang di sekolah siswa.

\section{Kesimpulan}

Berdasarkan hasil penelitian melalui penerapan model pembelajaran Example NonExample dapat meningkatkan hasil belajar siswa pada materi ekosistem. Selain hasil belajar juga diserta dengan peningkatan aktivitas siswa dalam berdiskusi, baik diskusi kelompok maupun diskusi kelas, mengamati gambar, menganalisa gambar, bekerjasama dengan kelompoknya, mengajukan pertanyaan yang terkait dengan materi pelajaran, mengemukakan tanggapan dan meminta bimbingan guru. 


\section{DAFTAR PUSTAKA}

Anisa, A., \& Ernawati, E. (2018). PENGARUH PROKRASTINASI AKADEMIK TERHADAP HASIL BELAJAR BIOLOGI SISWA SMA NEGERI DI KOTA MAKASSAR. Jurnal Biotek. https://doi.org/10.24252/jb.v6i2.6256

Arikunto, S. (2013). Prosedur Penelitian (15th ed.). PT Rineka Cipta.

Djafar, N. A. (2014). Penerapan Model Pembelajaran Example Non Example Untuk Meningkatkan Kemampuan Berpikir Kritis. Jurnal Bionature, 15(2), 67-80.

Leonard, \& Wulandari, F. (2015). Pengaruh Metode Pembelajaran Example Non Example Terhadap Hasil Belajar Matematika Siswa. Prosiding Seminar Nasional Pendidikan Matematika.

Sabroni, D., Koestoro, B., \& Asmiati, A. (2018). Pengaruh Model Pembelajaran Example Non Example berbantuan Poster Comment Terhadap Pemahaman Konsep Matematis. NUMERICAL: Jurnal Matematika Dan Pendidikan Matematika. https://doi.org/10.25217/numerical.v2i2.315

Soenarno, S. M., \& Sari, A. (2020). Penerapan Model Example Non-Example untuk Peningkatan Pemahaman Mahasiswa dalam Pembelajaran Biologi Sel. Prosiding Seminar Nasional Sains, 1(1).

Sugiyono. (2017). Metode Penelitian Kuantitatif, Kualitatif dan R \& D.Bandung:Alfabeta. Metode Penelitian Kuantitatif, Kualitatif Dan $R \quad \& \quad$ D.Bandung:Alfabeta. https://doi.org/10.1017/CBO9781107415324.004

Suryani, E., WS, R., \& Nugraha, A. (2018). Pengaruh Model Example Non Example terhadap Hasil Belajar pada Materi Sumber Daya Alam di SD. PEDADIDAKTIKA: JURNAL ILMIAH PENDIDIKAN GURU SEKOLAH DASAR, 5(1), 100-108. https://ejournal.upi.edu/index.php/pedadidaktika/article/view/7229

Susanti, R. (2014). PEMBELAJARAN MODEL EXAMPLES NON EXAMPLES BERBANTUAN POWERPOINT UNTUK MENINGKATKAN HASIL BELAJAR IPA. $\begin{array}{llll}\text { Jurnal Pendidikan IPA Indonesia, } & 3(2), & 123-127 .\end{array}$ https://journal.unnes.ac.id/nju/index.php/jpii/article/view/3110/3127

Tulhikmah, R. (2019). Keefektifan Model Pembelajaran Kooperatif 'Tipe Examples Non Examples' terhadap Hasil Belajar Siswa SMA. Tarbawy: Jurnal Pendidikan Islam, 6(1). https://doi.org/10.32923/tarbawy.v6i1.859 